\title{
Another History of Museums: from the Discourse to the Museum-Piece
}

\section{Dominique Poulot ${ }^{1}$}

ABSTRACT: The history of museums could get inspired on the procedures of material studies and of Anthropology in order to take a new stand and move away from the institutional approach and consider the approach of objects traditionally labelled as museum objects. The so-called "museum pieces" are supposed to have a number of characteristics, particularly some great historical and artistic qualities, sometimes an heritage quality, but above all the ability to make "friends" around the community or around the world. In all these respects, it is proposed here a number of research procedures that may supplement or enrich the directions usually assigned to the history of institutions.

KEYWORDS: History. Museums. Objects. Museology. Heritage.

RESUMO: A história dos museus poderia se inspirar nos caminhos dos material studies e da antropologia para rever seus pontos de vista, e passar do ponto de vista da instituição para aquele dos objetos tradicionalmente qualificados como objetos de museu. A definição desses objetos evoca um certo número de características, sua qualidade, particularmente a qualidade histórica e artística, ou ainda patrimonial, a capacidade de suscitar "amigos" em torno deles, enfim, sua utilidade pública. Sob todos esses aspectos, propõe-se aqui uma série de caminhos de pesquisa que podem completar ou enriquecer a direção que normalmente se dá à história das instituições.

PALAVRAS-CHAVE: História. Museus. Objetos. Museologia. Patrimônio.

RÉSUMÉ: L'histoire des musées pourrait s'inspirer de la démarche des material studies et de l'anthropologie pour réviserson point de vue, et passer de celui de l'institution à celui des objets qualifiés traditionnellement d'objets de musée. Leur définition évoque uncertain nombre de traits, laqualité, en particulier historique et artistique, ou encore patrimoniale, lacapacité à susciterautour d'euxdes "amis", enfin l'utilité publique. Sous tous ces aspects, on propose ici une série de démarches de recherche susceptibles de compléter ou d'enrichir la conduite habituelle d'une histoire des établissements.

MOTS CLÉS: Histoire. Musées. Objets. Muséologie. Héritage.
1. Université Paris 1 - Panthéon-Sorbonne. E-mail: $<$ dominique.poulot@univ-paris1.fr>. 
2. Cf. Geoffrey Lewis (1989).

3. Cf. David Murray (1904).

4. Cf. Bruno Latour (2005, p. 21).

5. Cf. Gwendolyn Whright (1996).
The museum as a European invention was considered a model for the world, at the very least since the foundation of the first professional museum association (the Museums Association, 1889/2 but also in the overview publications of the beginning of the twentieth century. ${ }^{3}$ The museum is today experiencing a worldwide expansion of both its cosmopolitan and universal version but also as an institution for the promotion and claim to particular cultural identities. This phenomenon is such that beyond confrontations concerned with particular types of objects or museological philosophies, the most remarkable observation is this seemingly general triumph of a particular status that is at once, legal, scholarly, technical and public, and which is that of the so-called "museum piece", that is an object of a peculiar quality.

An underlying principle of museums has always been division: they demarcate a space from that of normal uses, but we know that the social life of things doe s not end when objects enter the museum. In the name of the interests of participative communities, of adaptative reuses, for example, some hhinterprets of museology today want to take the objects and images outside the museums. But we need to think about the possibility of a third space that crosses over from each side of this apparent divide, and which is the expression of a certain agency of objects. One famous example of the work - and even defence - about these borders between the museum and the society can be found in the work by Bruno Latour to use the exhibition as a fair, as a space for an assembly of assemblies, and tangible presentations of the public affairs. "Scientific laboratories, technical institutions, marketplaces, churches and temples, financial trading rooms, Internet forums, ecological disputes - without forgetting the very shape of the museum inside which we gather all those membradisjecta - are just some of the forums and agoras in which we speak, vote, decide, are decided upon, prove, are being convinced" . 4

We must challenge some of the totalizing narratives about the history of museums, and especially the binary logic of their interpretation as spaces of social control or as temples and cathedrals, using more diverse categories about the moral economy of "precious" things. We must deal with the appropriation of objects that are qualified as "museum pieces". This is a process at work in defining objects held to be precious and used in the expression of claims to and the management of public property. The cognitive and emotional attachments that developed through the contact with these museum pieces is in fact essential - be they real and physical or through other media that extend the impact of the establishment. Thinking in this way about how museums negotiate their cultural authority would contribute to opening up new directions of research in museums and material culture history, associated with the definition of the state, civil society and public space.

Histories and Traditions

A majority of museum histories take on the form of portraits dedicated to individual institutions constructed in national contexts ${ }^{5}$, with the exception perhaps of the study of museum origins and early beginnings, which have been the object of 
collective studies that bear witness to the cosmopolitan nature of the Enlightenment ${ }^{6}$. The museum's own memory, generally commemorative, aims to produce either an overall study dedicated to its architecture or to the history of the growth of its collections, or to provide a dictionary of people and places. ${ }^{7}$ Thus museum history has been dominated by an approach dedicated either to the history of the collections or to the topography and organisation of the display spaces (this approach is perhaps best exemplified by Aulanier's monumental work on the Louvre). ${ }^{8}$ Museums have also provided the focal point for a history of disciplinary developments?, as the institutions were regularly described as the homeland of certain fields of study intimately related to material culture. Germain Bazin provided a study of the birth of art history intimately bound up with the emergence of the museum. ${ }^{10}$ The analyses of nineteenth-century visual culture that dates back to the 1970s renewed these approaches, notable the seminal work by Richard Altick, The Shows of London"1 dealing with the spectacles in the early-nineteenth-century capital, which included panoramas, waxworks, and human showcases. ${ }^{12}$

Since then, a crucial idea stated that museums were founded to achieve political and social objectives - to influence the moral and intellectual conduct of the citizen and to provide declarations of national identity as assertions of certain views of history or culture. James Sheehan argues that "among the significant artifacts that museums contain are the intellectual, institutional, and architectural traces of their own history, residues of their own past". ${ }^{13}$ Museums were monuments to their age, producing "master narratives" of liberal reform and urban government, and following the trends of democratization. ${ }^{14}$ Enquiries into the nationalization or institutionalization of culture found ${ }^{15}$ museums to be ideal sites for understanding the institutional politics of nationalism. ${ }^{16}$ Carol Duncan's and Allan Wallach's influential essay described museum-going as a civic ritual that naturalized the democratic nation-state. ${ }^{17}$ Every major public collection during the nineteenth century tried to keep a balance "between a museum, like the British Museum, where specimens are put together to reveal a progression or a pattern, and a gallery, where the individual work of art is meant to be seen and enjoyed on its own.". 18

Most narratives about the history of museums describe it either as a logical process of progressive democratization (the passage from places of privileged access to generalized access) or as spaces of social control specific to the development of liberal government according to a post-Foucauldian perspective ${ }^{19}$, or lastly as the cultural model, the museum temple of universal art which supposedly led naturally to Europe's domination of art history and heritage consciousness in the 21 th century. ${ }^{20}$ In a field of study that is by nature multidisciplinary, at the crossroads of cultural and material studies, developing along theoretical lines provided by the social sciences and humanities, the historian's response has been to undertake a selection of those studies that appear to satisfy the objectives of his own discipline, leaving aside the others. ${ }^{21}$

But instead of the one-sided view of institutional success, another approach consists of considering the interaction between museum objects and their
6. Cf. Ellinor Bergvelt et al. (2009); Carole Paul (2012); Edouard Pommier (1995).

7. Cf. Michèle Van Kalck (2003).

8. Cf. Christiane Aulanier (1948).

9. Cf. Christopher Whitehead (2009); Simon Knell (2000).

10. Cf. Germain Bazin(1967).

11. Cf. Richard Altick (1978).

12. See also the project $<$ http://www.exhibitionculture.arts.gla.ac.uk/>, which documents the history of exhibitions in late nineteenth century London: "Its aim is to explore the everyday world of commercial art dealers, artist led exhibition societies and clubs by recording the vast spectrum of art displays on offer to the Victorian gallery visitor at any given moment in time".

13. Cf. James Sheehan (2000, p. 189).

14. Cf. Kenneth Hudson (1975).

15. Cf. Jannet Minihan (1977).

16. Cf. Marcia Pointon, 1997; Domique Poulot (1997); Thomas Gaehtgens (1992).

17. Cf. Carol Duncan and Allan Wallach (1980).

18. Cf. Neil Macgregor (2004, p. 30).

19. Cf. Flora Kaplan (1994); Daniel Sherman and Irit Rogoff (1994); Tony Bennett (1995).

20. Cf. James Cuno (2009).

21. Cf. Randolph Starn (2005). 
22. Cf. Erno Marosi and Gábor Klaniczay (2006); Jonathan Conlin (2006); Berward Deneke and Rainer Kahsnitz (1977); Lote Jensen et al. (2010); Christophe Loir (2004).

23. Cf. Jonathan Conlin (2001).

24. Cf. Arjun Appadurai (1986, p. 5). See also the 'object-based epistemology' used by Amiria Henare (2005).

25. Cf. Alfred Gell (1998); Robert Layton (2003).

26. Cf. George Stocking (1985).

27. Cf. John Brewer (2009).

28. Cf. Lorraine Daston (2004); Susanne Lehmann-Brauns et al. (2010).

29. Cf. James Cuno (1997).

30. Cf. Sarah Byrne et al. (2011, p. 4).

31. Cf. Mary Anne Staniszewski (1998).

32. Cf. Bill Brown (2011).

33. Cf. Nicholas Thomas (1991). "friends". The subject of analysis would be the complex process that has been central to the social life of things over the last two centuries, an acculturation of the museum by society as it developed a literacy of museums and exhibitions. ${ }^{22}$ The museum thus transpires to be a site of legal innovation and cultural creativity, of pride in community and nation, between social consumption, leisure, and, of course, politics - according to the role it played between high art and legitimacy, for example. ${ }^{23}$

What is at stake here is to write a history not of the institution of the museum, but of the museum object that takes into account the most recent approaches in the sociology of objects. Over the past two decades the recognition and rise of material studies and consumption studies, the anthropology of the material world or the material history of art have focused on questions related to how objects mediate social relationships - ultimately how inanimate objects can be read as having a form of subjectivity and agency of their own, in a kind of "methodological fetishism" as Ariun Appadurai coined it. ${ }^{24}$ The idea of an agency as Alfred Gell imagined it has been immensely successful in the anthropology of art, even if its denial of any reception theory is problematic. ${ }^{25}$ This dimension invites us to try to understand and analyze the productions of artefacts as well as the mutations related to different uses and contexts. ${ }^{26}$ Finally, a whole new current has begun to deal with the construction of spaces of international exchange created by the circulation of objects, things, merchandise and notably the transatlantic business of works of art. ${ }^{27}$ In brief, the question of the utility of the museum by considering "things that speak" is a fruitful theme in material studies today, that needs to be adapted to the question of the display of specific types of objects. ${ }^{28}$

At the heart of this kind of project are the interactions between museum objects and their different publics or societies: there are those who invest time and money and use these activities to express ideals and life aims but there are also those who seek out the museum and its objects for study or for leisure. ${ }^{29}$ More generally, museums are not only "material assemblages but also social collections". ${ }^{30}$ They may be considered to bear witness to a European cultural landscape that is characterized by the intensity and the changing modes of a specific kind of material culture. The aim is to avoid two stumbling blocks: that of the art historian who has traditionally implicitly accepted the autonomy of the artwork and ignored "the power of display"31 and an approach that gives credence to the "myth of the precedence of things" 32 in relation to "ideas, theories, words". In order to achieve this, we need to locate the discourses and narratives that crystallise around the reference to objects, without losing sight of their material nature. ${ }^{33}$

Negotiating Values, Possession and Knowledge

The museum world is dominated today by the heated debates on issues of heritage and the ownership of culture: who can legitimately claim to own a great work of art - an individual proprietor, a culture, the nation, or humanity? How do 
the different actors and consumers involved use objects to elaborate their identities? It was Margaret Mead who first expressed the idea that in order to understand a society's culture it is helpful to consider the "sort of biography it regards as embodying a successful social career". ${ }^{34}$ Igor Kopytoff has suggested applying the same reasoning to the "biographies of things". More specifically, Kopytoff focuses on the cultural process of commoditization of objects - he wants to study which objects can appropriately be characterized as a commodity and which cannot, and how the constitution of this dichotomy operates within a moral economy. The cultural valuation of objects creates individual- and group-specific ordering of spheres of exchange based on what is socially appropriate and morally advisable. This new culture of the museum was orchestrated by connoisseurship and by the scholarly discourses of the cultivated in the name of the relationship between the ideal life of an object and the ideal life of a person.

The expression "museum piece", though attached to a plurality of meanings in different European languages, preserves a normative core. This construction of the museum piece is an essential aspect of the procedures and practices that define the institution from an anthropological perspective. Even though work using such an approach may still be in a sense controversial and debated ${ }^{35}$, an appreciation of the world of the museum should greatly profit from their perspectives on the social role of material culture. We must understand the system of singularization that places a certain number of objects outside of the normal commoditization process (a process that nevertheless served to evaluate them initially) and transforms them into museum pieces, even in a close relationship with the commercial world. ${ }^{36}$ This is part of what can be called the Musealization Complex, at the heart of an "expanding chaos of images, commodities and stimulations" 37 that characterized the culture of objects and multiplication of visual imagery from the nineteenth century onwards.

Whilst analyses abound on the status and history of 'curiosities', archives or master pieces as much from the perspective of the history of ideas ${ }^{38}$ or from that of the social sciences - considering professional expertise or fakes ${ }^{39}$ - no study has ever been dedicated to the situation and representation of the museumpiece. The historian's perspective considers the museum piece as another element of the visual representation of the state, such as flags, emblems, monuments, banknotes and stamps, which of course tends to neglect its specificity. On the other hand, art historians extract it from its physical site and display to only consider aesthetic or scholarly value, by developing a discussion of what appears as its intrinsic qualities, to the detriment of an appreciation of different strategies of interpretation related to its use in exhibition practices. Finally, museum studies literature is mainly dedicated to the social history of the museum institution itself, and not the objects it contains - even though certain typologies of the multiple kinds of agency expressed in the complex long-term historical processes that contribute to museum collections have been published, often in an archaeological perspective. ${ }^{40}$ In the museum, pieces can appear as "clever" or dumb objects. ${ }^{41}$
34. Cf. Igor Kopytoff (1986).

35. Cf. Janet Hoskins (2006); Bruno Latour (1993).

36. Cf. Jonathan Conlin (2000).

37. Cf. Jonathan Crary (1999)

38. Cf. Walter Cahn (1979).

39. Cf. Christian Bessy and Francis Chateauraynaud (1995); Thierry Lenain (2011).

40. Cf. Sarah Byrne et al. (2011).

41. Cf. Art History (2013). 
42. Cf. Arthur Danto (1981, p. 125).

43. Cf. Suart Hall (2001).

44 Cf. Kate Hill (2005); Dominique Poulot (2012a).

45. Cf. Tim Barringer and Tom Flynn, ed. (1998). obviously the institution may fail to recognize the true quality, but it always interprets the object in the Danto's sense of a "transfiguration of the commonplace". 42

Beyond the permanent character of museum ownership, how do museums act as "temporary stabilizers" 43 of heritage and its related communities as performed in temporary exhibits? In the singularization process that sanctions the entry of objects into the museum the rationale of these processes must be considered as the intertwined result of institutional history and the biographies of various actors - curators, donors, merchants. ${ }^{44}$ It is necessary to locate in these texts the vocabulary, formulas and expressions that express notions related to the opposition between private and public property, ideas of quality and public utility: in other words the recognition of a moral economy related to these objects.

In general, the atlas of European museums is characterized by a kind of static image of these institutions, despite the fact that in reality they are anything but. One can in fact observe considerable circulation of museum property in a system of exchange of temporary appropriations. An enquiry into the circulation of objects organized by museums at different levels and according to different objectives needs to be carried out as they provide important keys to understanding the classification, appreciation and the attribution of importance to objects.

The circulation of objects related to some great events such as wars, looting or political turnmoils has given rise to a specific discourse justifying their displacement, expressing the cultural importance that is attributed to these European "grand tours" of the objects, that include capitals and major cities but also may offer a temporary presence in more peripheral zones. Inversely, certain objects are excluded from any loan system, endowing them with specific distinction, as they are considered as attached to the site of their conservation. The displacement of objects from colonial settings provides another context for the definition of a hierarchy of objects to be saved. ${ }^{45}$ Lastly comes the question of restitutions, after wars or in the post-colonial context, but also of object loans. The political and legal discourses, but also in certain cases the religious considerations related to these cases, can lead these restitutions to be accompanied by specific rituals, that are important subjects for the history of values of appropriation.

On the horizon of these analysis one can examine the limits of the museum's control of certain objects, certain icons or some pieces related to more local attachments; they make it apparent when the museum is too large, too vast to deal with the claims of local attachment or on the contrary too small for it to play in a global network of influence. We need to inventory elements of the answers to these paradoxes and these limits of the museums, according to ever changing frontiers, without indulging in the endlessly antagonistic issues related to restitution debates.

The traditional corollary of any attachment to objects, of the success of any museum piece, is the production of copies, present since the invention of a long series of different reproduction techniques. The copy has always occupied an important role in the art museum, in schools and art academies across Europe, as it 
has in the birth and development of art history ${ }^{46}$, but it functions also as a heterotopia of the museum: as a compensation for immovability and regulation. In parallel, a more banal kind of commercial reproduction was developed ${ }^{47}$ such as the reproduction of medieval furniture from Cluny that was sold throughout nineteenthcentury Paris. ${ }^{48} \mathrm{New}$ graphic techniques, the legal development of copyright, and the rise of the art market and art publishing resulted in a wide distribution of printed reproductions to the general public during the second half of nineteenth century. ${ }^{49}$ Such phenomena are the clearest illustration of the idea that in the analysis of a public collection the important point is to capture things "less in as much as they crystallize the extent of work or energy and more in as much as they multiply it" 50 . For indeed the list of reproductions distributed at different levels across Europe provide a map of the cosmopolitan force of the museum piece, as one takes into account the hostility - or reverence - manifested in relation to certain "national" objects inside of transnational collections. In a certain sense, the sale of copies of museum pieces illustrates how the museum diffused a set of values, and for example a set of images of domesticity, family, patriotism, that are comparable to other processes. ${ }^{51}$ One must look at museum objects not in the elitist view that considers only the museum as a muse, but as part of a larger world of precious objects, for which it has become the modern reference, one whose power enjoys increasing hegemony.

We know that the development of expertise is inseparable from processes of collecting. ${ }^{52}$ According to the perspectives developed by anthropologists and cultural critics inanimate objects take on life through their interpretation - notably, in our culture, as they are collected and housed in museums: "An object becomes interpretable only in the context of a 'society of friends'". 53 Museum objects have been interpreted in an inseparable manner by those amateurs, such as private collectors or the art market professionals, and by those who are often perceived as their enemies or rivals : the curators of the museum - yet all of them in fact claim to be "friend" of these objects. We need to know better here the educational modalities and the curricula offered to those seeking to work in the museum world as curators or conservators, be it the École du Louvre (1882) the Museums Association (1889), the Reinwardt Academy or the multitude of important centers for museology that now exist. ${ }^{54}$ There is a circulation of models of expertise in the conservation and display of objects - models that were more or less inspired by disciplines related to the establishment of museums, to the market, to universities 55 or to "civic laboratories". 56 Particular attention must be paid to the elaboration of strategies designed to make the objects more useful for the public, i.e. the "lessons of things" in the tradition of Pestalozzi, the application of intuitive methods right up to the elaboration of public policies set out to promote the benefits of museum collections.

The literature produced by collectors and curators (and not only by declared museophobes) has over time come to build an apparently inverted imaginary of the museum, which is in reality quite complementary to its official issues related to education. That of the museum as an expression of the refusal of knowledge
46. Cf. Ingrid Vermeulen (2010); Ellinro Bergvelt et al. (2011).

47. Cf. Florence Rionnet (1996).

48. Cf. Elizabeth Emery (2003); Bonnie Effros (2008); Anca Lasc (2013).

49 Cf. Robert Verhoogt (2007).

50. Cf. Lorraine Daston (2004).

51. Cf. Dianne Macleod (1996).

52. Cf. Arjun Appadurai (1986); Joseph Alsop (1982).

53. Cf. Miguel Tamen (2009).

54. Cf. Jesús Pedro Lorente (2012).

55. Cf. Bruno Latour (1993).

56. Cf. Tonny Bennett (2006). 
57. Cf. Marcia Pointon (1997).

58. Cf. Anthony Smith (2003; 2004).

59. Cf. Susan Crane (2000).

60. Cf. Francesco Orlando (1993); Dominique Pety (2010); Janell Watson (1999); Caroline Patey and Laura Scuriatti (2009).

61. Cf.Paula Findlen (1989).

62. Cf. Sharon Macdonald and Gordon Fyfe (1996).

63. Cf. Elizabeth Emery (2012); Anne Higonnet (2009).

64. Cf. Odile Vincent (2011); Kate Darian-Smith (2012). and pedagogy, a space expressing values of intimacy and shows of expenditure, often in reference to a golden age of curiosity, all for the pleasure of satisfying taste. ${ }^{57}$ Here one might refer to Anthony Smith's reflections on how golden ages come to be established in collective representation. ${ }^{58}$ The praise (and critic) that antagonistic forms of developing museum pedagogy receive in the second half of the nineteenth century might be a correlated to those reactionary collections dedicated to the memory of defeats (such as the nostalgic collection of elements related to the frenchancient régime), but also the result of collection engagement that finds itself deprived of meaning by the opening of museums such as was the case in Germany ${ }^{59}$ and doubtlessly also in Italy after national unification. Going beyond the role of objects within the realm of education, one need to take into account the production of a discourse that defines those liminal senses of place, those examples of crisis where an object's "meaning" seems to be erased somewhere between being thrown away and placed in a museum. We have yet some various researches conducted in the literary field 60 but we need to apply them in a different way. Because, contrary to the preconceived notion that the modern museum unified and harmonized a variety of practices, "crystallising and incorporating what formerly appeared to be a certain number of disparate activities" 61 , the last two centuries informal processes and private concerns consistently crossed paths with professional museum practice and its actors.

The trajectories of museum objects

Some museum objects can be qualified as frontier objects, to employ the vocabulary used in the sociology of science, in as much as they refer to different communities of interpretation. The most obvious way of getting at this question is the definition of objects representing national identity, as can be analyzed in the case of collections established as the result of conflict with the aim of learning lessons from the past in a proactive manner. ${ }^{62} \mathrm{~A}$ museum specifically dedicated to the history of conflict in Europe such as the museum of the Bibliothèque de documentation internationale contemporaine at the Invalides in Paris, or the many Museum Memorials throughout Europe, locate national objects in as much as they are placed in an explicit parallel with those of the other - the enemy or the ally. In such museums dedicated to historical criminality one might ask oneself to what extent the explicitly pedagogical and commemorative ambition defined the type of objects collected - and how it is used either to maintain hatred of the enemy, to consolidate an imaginary community of resistance, or to make a universal statement for peace. An opposing case is that of museum objects that are supposed to provoke a sense of communion or at the least respect for the past and its actors; such as those relics and traces left behind by celebrated figures, great men in house museums turned into sanctuaries. ${ }^{63} \mathrm{~A}$ consciousness of the gendered issues of these collections is here important, and also their possible relation to the collecting by children. ${ }^{64}$ By analyzing the status of the museum-piece according to such vectors, implies thinking about the 
reception of objects in sentimental terms and as an education in visual literacy ${ }^{65}$ : one may contribute to the history of emotions by asking, for example, what it might mean to cry in the museum. ${ }^{66}$ Eventually, the relation to the museum object is far from being a singular, isolated face to face. In fact the relation to objects in museums is more akin to a kind of nomadic narrative, as the visit to a museum always includes a journey, that may be accompanied by moments of fatigue and apathy but also and more so by emotions related to identity and attachment.

The question of the entry of objects into museums more or less explicitly asks about a rupture or specific phase in the long life of images and objects: the history of the museum was for a long time understood according to the glorifying logics of collectionism or on the contrary as a narrative of reparation in relation to objects unduly seized and assembled. Today the perspective is more dialectical, one between "Possessors" and "Possessed" objects. ${ }^{67}$ The museum appears as the "home" of art and knowledge, a place that is experienced as one passes through it: it valorizes the liberal culture of the right to property as the ideological basis of society's political system but also the visible manifestation of the democratic access to pleasure and knowledge.

The history of the movement of works between different owners and through different types of collections provides the starting point from which to begin any examination of the constitution of a culture taking possession and ownership. The gesture of legacies and donations to public museum appears often through the texts that refuse or contest the principal of the public institution in the name of antagonistic values that are in reality complementary.

The contradictions between the meaning of an object in its environment and its place in the development of institutions such as the museum that become the ideal depository and shelter of all artistic industries, clearly became apparent at the same time as the development of nationalism in the first third of the nineteenth century - even if it its premises were visible earlier, as in the case of the collections of the Italian peninsula, that were being heavily bought up by foreigners, especially British collectors. Discussions related to property and legitimacy were central in the formation of a new collective culture of ancient art, considered as a heritage of useful models for national schools of art, as much as for the progress of knowledge. An especially sensitive issue was that of the legitimacy of the artistic conquests, assembled in France's museums, in the name of liberty; whilst at the British Museum, the debates surrounding the acquisition of the Elgin marble expressed claims of the legitimate right to own this heritage of Greek freedom, arguing for it as the natural destination of an art whose inspiration was to revitalize British artistic production. ${ }^{68}$. As an institution, the new museum of the nineteenth century was the vessel of international rivalry - built to avoid the dispersal of the nation's heritage, it was also at the heart of an international race to unite the greatest new collections, in particular on the archaeological front. 69

The analysis of such debates needs to take into account the history of those philanthropists and patrons who, in a number of cases, hoped to gain in
65. Cf. David Freedberg (1991).

66. Cf. James Elkins (2004).

67. Cf. Wendy Shaw (2003).

68. Cf. Dominique Poulot (2012b).

69. Cf. Ian Jenkins (1992). 
70. Cf. Thomas Adam (2009); Veronique Long (2007).

71. Cf. Sandra Dudley et al. (2012).

72. Cf. Jordana Bailkin (2004); Brandon Taylor (1999).

73. Cf. Arjun Appadurai (1986).

74. Cf. Marcia Pointon (2009). respectability by contributing to the growth of public collections. ${ }^{70}$ It also needs to include the history of those social reformers who pleaded in favour of the positive values of the museum as a place that allowed visitor to be inspired by most elevated ideals. However, the affirmation of the museum's value was questioned by different members of the public such as those collectors who felt that the social life of the object was endangered by the museum piece status, and who considered their private appropriations as superior. ${ }^{71}$ A critic of the institution was also a subject for economists, philosophers and political scientists participating in public debates that began to take place in the nineteenth century, considering the uses and abuses of museums. These debates relate the museum to questions of political theory, to the notions of individualism and liberalism, philanthropy and the role of public institutions.

The history of the ties between princely, national and state property and the private possessions of collectors reflects via the question of art, the state and its attachment to its heritage, important confrontations in terms of social legitimacy. Specifically after the French Revolution, the collector's bric-à-brac became the only way of accessing a bygone time, of holding on to a memory that was contrary to the interests of official history writing. More generally speaking, throughout the nineteenth century, the relationship between public and private property progressively defined liberal ideology (the demonstration by Bailkin for the english case is eloquent ${ }^{72}$ ). The status of the collector or amateur was also progressively determined, as a reference to a particular sensibility, to forms of attachment, though related to a long tradition of collecting that took on a new tonality.

The testament of the amateur Edmond de Goncourt constitutes an archetype of the discourses that express a rejection of the museum principal by affirming that possession is the most intimate relationship that one can entertain with an object. But in fact the circulation of practice from the private to the public sphere is a key element to understanding the culture of museums. Generally speaking, the activity of philanthropists in the development of the museum, whether desirous of benefiting from greater respectability or driven by other motives, reveals the permeability between the action of collectors and the curators of public museums, who often share ties of friendship (be they of an interested nature) meeting in the sales room of the auctioneer as much as in the rooms of the museum itself, publishing and reading the same literature. In certain respects these ties can be considered as signs of the unclear lines that separated leisure and professional activities at this time.

Whilst the role of the museum as a space of political control of liberal economy can clearly be shown to be played out in the "exhibitionary complex" that it incarnates, the question of its relationship to property rights and to their representations, or to the "social life of objects"73 appears as far less obvious to resolve. ${ }^{74}$ For example, the curator could chose a mode of display that was a reference to the private sphere, through the development of period rooms whose objective was to provide the illusion of a space elsewhere in another time. 
The evolution of the philosophy of the museum in the course of the nineteenth and twentieth century is very much bound up with provision of specific dispositions for the benefit of the visitor, in as much as they illustrate its objectives of moral persuasion and control of the body. The history of the institution of course involves those debates on the morality and utility of the museum, on its contribution to social well-being and self-accomplishment. The discourse on the museum has strong political implications, as has been shown in Britain with the question of municipal investments and the professionalization of curators. ${ }^{75}$ The title of the famous article published in 1883 by the English philosopher and economist, W. Stanley Jevons, The Use and Abuse of Museums ${ }^{76}$, shows the emergence of a collective interrogation concerning the economy of culture as related to political science and to organisational theory. The discussion concerning the legitimate use and the excessive development of museums was also lively in France, as can be seen during the period of the reorganization of the national museum network around 1945, especially in the writings of Georges Salles. ${ }^{77}$

Another aspect of the "abuse" of museums is the excess of mobility of their collections. The formation of ephemeral collections has been reconfiguring the value of objects from the very beginning of such events (in 1857, Manchester ${ }^{78}$ ) and at different levels, the most obvious being the recent creation of the so-called "Bizot Group" or the "lending for Europe" project that aims to facilitate museum object mobility. The manner of installation and display of objects on these occasions modifies the status and image of museums: their circulation de facto reinforces the hierarchy of institutions. Their resources and their consequent capacity to participate in these exchanges define them as the partners and rivals of other institutions. These" ephemeral museums"79 have a great role since the end of the nineteenth century in giving museums objects greater visibility, all the while remaining invisible as a terrain for scholarly enquiry.

The status of this mobile property, considered from the point of view of a selection of major national museums on the one hand and from a selection of specialized exhibitions dealing with specific territorially defined heritage, would allow for the identification of privileged networks of circulation and a larger analysis of the question of cultural transfers in Europe, highlighting the specific role of "ambassador objects". A particular case of this are mobile museums that appeared in the middle of the twentieth century, but have proliferated alongside the effort to expand the perimeter of the traditional Museum by using mobile structures (the temporary pavilions of the Serpentine Gallery since 2000 or of the Center Georges Pompidou for example).

The first museums were filled with numerous copies, intermingling with spolia and fragmented works, reassembled or recomposed for pedagogical purposes. Later the copies became unworthy of the museum. ${ }^{80}$ But the museum
76. Cf. Stanley Jevons (1883).

77. Cf. George Salles (1948).

78. Cf. Elizabeth Pergam (2011); Dianne Macleod (1996).

79. Cf. Francis Haskell (2000).

80. Cf. Gordon Fyfe (2004). 
81. Cf. Michael Falser (2011).

82. Cf. Anne McCauley (2008); Sian Bayne et al. (2009).

83. Cf. Antoine Hennion and Bruno Latour (2003).

84. Cf. Robert Nelson (2000).

85. Cf. Kate Scott (1998); Ronan Deazley, Martin Kretschmer and Lionel Bently (2010).

86. Cf. Mieke Bal (1994)

87. Cf. Ladislav Kesner (2006). remains always a work place and source of livelihood for many of the more modest workers in the world of art. The production of copies was a quasi industrial activity in museums in the nineteenth century, taking on different forms, sometimes in response to outside demand, sometimes at the initiative of the institution itself, carried out by the services of printing and plaster copy workshops ${ }^{81}$ and later through the means of prints and photographical reproduction until the arrival of digital imagery. ${ }^{82}$

By examining the museum as a place for the reproduction of images and objects it is related to the renewed field of studies devoted to the market, to intellectual property laws, to techniques of reproduction. The production of copies and their dissemination is the most obvious sign of the museum's productivity. A long tradition of catalogue publication began with the creation of the first museums, as numerous artists and scholars worked to illustrate the quality of its resources. The painter Samuel Morse's initiative to reproduce the entirety of the major masterpieces in the Louvre, in order to establish an art school and the basis of solid connoisseurship in the United States, is perhaps the most significant example of the hopes that were placed in the potential of the reproduction of the museum piece.

In the particular case of print sellers of the famous Goupil merchant house in Paris and its branch sale rooms throughout Europe and across the Atlantic, the reproductions on sale were displayed in spaces modeled after the Salon carré in the Louvre, giving an official and museumlike allure to the exhibition and sale of their copies. The copies reassure as to the value of the originals, they even produce the aura of the original according to the sociological reading influenced by the school of Bruno Latour ${ }^{83}$, thus inverting the theory developed by Walter Benjamin according to whom the art work had lost its particular aura with the age of technical reproductibility. ${ }^{84}$ But these processes of dissemination of objects and images due to the activity of museums themselves - as owners and guardians - are related to the negotiation of legal constraints and technical issues of reproduction. One difficulty, varying from country to country is the question of copyright and its evolution (as Katie Scott described it in France ${ }^{85}$ ). It is connected to that of the representation of authenticity and the quality of the museum object compared to market objects and family or private objects in a dialogue between the regulation of the copy on the market and the protection of the museum's property.

The work of the museum is an internal one of recording, preservation and conservation, of study and publication but also of the organization of the reproduction of the object for pedagogical and commercial ends. It includes orchestrating explicative narratives that orientate the interest to be invested in the object. The object's final creation so to speak is the narrative that the expert or the visitor produces as a reaction to his encounter and engagement with the object in the museum context. ${ }^{86}$ During the nineteenth century all of the amateurs of the museum world tried to understand how the contemplation of art works might impact on the visitor and how museums might weigh in on the balance of public taste and develop certain competencies. ${ }^{87}$ In a similar vein to the question of public literacy, enquiries considered how to mould character, reform taste, inspire a sense of emulation and 
elevate minds. The literature dedicated to the question of persuasion is of interest here, as art history has often been defined as a form of conversation: the presentation of its results is the result of museum's power. ${ }^{88}$ Medical and psychological observations ${ }^{89}$ concerning the senses showed how vision gives rise to sympathies, attachments and benevolence towards art and its industries..$^{90}$ However a certain apprehension of misuse also appeared, about some of the possible misappropriations of museums by the masses at the end of the century.

An extraordinary number of novels, poems, plays devoted to this topic over the course of the nineteenth century were complemented by various forms of criticism about curiosity and art collecting, in particular artist monographs, biographies and necrologies, as well as collector's own writings, such as autobiographies and correspondence. Such writings are seminal in the creation of the collection, private but open to a public, as a social type in popular imagination. As with visual imagery, an iconography of the collection "painted in words" is essential to understand the emergence of the museum as a public figure. It forms a central theme in the reflection of the 1880s to the 1940s, a period when a kind of horizon of expectations in terms of the correct way to envisage the museum visit was being formulated. This literature concerning the power of art as persuasion must be replaced in the context of the discussion concerning questions of taste and moral recommendations that can be found in a variety of formats - travel diaries ${ }^{91}$, biographies, sermons. During the XXth century the new medium of cinema, after the photography, created a new visibility and attachment for new museum pieces, one example being Carlos Vilardebó's documentary La petite cuillère, 1966, about a choice of egyptian spoons of Petit Palais and Louvre Museums, which created a new interest for the quality of these little pieces beyond the specialists' world and connoisseurship.

The challenge for the historian, to take up the expression of Neil Harris, is to consider the museum experience like "a constant negotiation of values and meanings". 92 In this way, visitor practice must be conceived of as a social experience, and moreover as a political, aesthetic, and moral one, that is not without possessing an element of ritual magic ${ }^{93}$, combining leisure, work and selfaccomplishment. The idea of an attachment for the objects is orchestrated and represented in the literature that is at once descriptive and prescriptive (guides, autobiographies, narratives of visits, catalogues, curator's literature, etc). From the nineteenth century onwards, the museum visit is regulated by a new set of behavioural imperatives - self control, attentiveness, silence and immobility - all of these characteristics differentiate the visit from older practices - as has been similarly observed in relation to other forms of entertainment and public spectacles be it in the theatre or elsewhere. ${ }^{94}$ There were also differences between types of visitors; in some instances visitors belonging to the elite were allowed to touch the objects, behaviour that was justified and considered as correct, however the same gestures were forbidden and considered as illegitimate when attempted by lower social categories of visitors. ${ }^{95}$ The development of city leisure time, in the form the flâneur
88. Cf. Stankiewicz (1984).

89. Cf. Nélia Dias (2004).

90. Cf. Elizabeth Edwards et al. (2006).

91. Cf. Philippe Hamon (2001).

92. Cf. Sally Duncan (2002).

93. Cf. Mary Bouquet and Nuno Porto (2005).

94. Cf. Jonathan Crary (1999; 2002).

95. CF. Fiona Candlin (2008). 
96. Cf. Gregory Shaya (2004).

97. Cf. Benedict Anderson (1983).

98. Cf. Stephanie Moser (2010); Julia Noordegraaf (2004) strolling and taking in the shop window displays also had its influence on the development of a specific kind of museum gaze. ${ }^{96}$ But no less so did the caricatures and humoristic images that abounded in more or less specialized revues and the press, contributing to the establishment of interpretative models and rules of behaviour that in certain cases prove that the representation of the visit became an genre that did not necessarily faithfully reflect the reality of the visit but was rather the expression of imaginary and virtual possibilities.

The last two centuries tell of the triumph of the museum, as collections of displaced objects, sometimes restituted but always somehow appropriated. These foundations and metamorphoses of collections have taken entirely new legal, rhetorical and iconographical forms and at the same time they have incarnated the modern institution of culture. From this point of view, the boundaries between the private and the public, so fundamental to the process of the elaboration of the Nation-State and its representation of the heritage of an imagined community ${ }^{97}$, have always been negotiated. They are at the heart of a complex process of adjustments as expressed in a multiplicity of ideological, political, social and cultural debates - and intimately expressed by details of the displays of things. 98 The image of the "good collector", as well as the black legend of the museum, were thus forged in a dialogue with public establishments pointing to the philanthropic values of the ideal scholar, whilst the knowledge from the market has provided indispensable collaboration for the study, the exhibition and significance of the pieces.

\section{REFERÊNCIAS}

ADAM, Thomas. Buying Respectability. Philanthropy and Urban Society in Transnational Perspective, 1840s to 1930s. Bloomington: Indiana University Press, 2009.

ALSOP, Joseph. The Rare Art Traditions: the History of Art Collecting and its Linked Phenomena wherever these have appeared. London: Thames and Hudson, 1982.

ALTICK, Richard D.. The Shows of London: A Panoramic History of Exhibitions, 1699-1862. Cambridge: Belknap Press of Harvard University Press, 1978.

ANDERSON, Benedict. Imagined Communities. Reflections on the Origin and Spread of Nationalism. London/New York: 1991. [1983].

APPADURAI, Arjun. Commodities and the Politics of Value. In: APPADURAI, Arjun (ed.). The Social Life of Things: Commodities in Cultural Perspective. Cambridge: Cambridge University Press, 1986, p. 3-63.

ART History, Oxford, v. 36, n. 3 (The Clever Object), p. 468-676, jun. 2013.

AULANIER, Christiane. Histoire du Palais et du Musée du Louvre. Paris: Editions des musées nationaux, 1948 . 
BAILKIN, Jordana. The Culture of Property: The Crisis of Liberalism in Modern Britain. Chicago: University of Chicago Press, 2004.

BAL, Mieke. Telling Objects: a Narrative Perspective on Collecting. In: ELSNER, John; CARDINAL, Roger (ed.). The Cultures of Collecting. Cambridge: Harvard University Press, 1994.

BARRINGER, Tim J.; FLYNN, Tom (ed.). Colonialism and the Object: Empire, Material Culture, and the Museum. London and New York: Routledge, 1998.

BAYNE, Siân; ROSS, Jen; WILLIAMSON, Zoe. Objects, Subjects, Bits and Bytes: Learning from the Digital Collections of the National Museums. Museum and Society, Leicester, v. 7., n.2, p.110-124, 2009.

BAZIN, Germain. Les Temps des Musées. Paris-Bruxelles: Desoer,1967.

BENNETT, Tony. The Birth of the Museum: History, Theory, Politics. London: Routledge, 1995.

BENNETT, Tony. Civic Seeing: Museums and the Organization of Vision. In: MACDONALD, Sharon (ed.). A Companion to Museum Studies. Oxford: Blackwell, 2006.

BERGVELT, Ellinor; MEIJERS, Debora J.; TIBBE, Lieske; VAN WEZEL, Elsa (ed.). Napoleon's Legacy. The Rise of National Museums in Europe, 1794-1830. Berlin: G+H, 2009.

BERGVELT, Ellinor; MEIJERS, Debora J.; TIBBE, Lieske; VAN WEZEL, Elsa (ed.). Museale Spezialisierung und Nationalisierung ab 1830. Das Neue Museum in Berlin im Internationalen Kontext. Berlin: G+H, 2011.

BESSY, Christian; CHATEAURAYNAUD, Francis. Experts et faussaires: pour une sociologie de la perception. Paris: Métailié, 1995.

BOUQUET, Mary; PORTO, Nuno (ed.). Science, Magic and Religion: the Ritual Processes of Museum Magic.New York \& Oxford: Berghahn Books, 2005.

BREWER, John. The American Leonardo: a 20th Century Tale of Obsession, Art and Money. New York: Oxford University Press, 2009.

BROWN, Bill. Thing Theory. Critical Inquiry, Chicago, v. 28, n. 1, p. 1-22, aut. 2001.

BYRNE, Sarah; et al (ed.). Unpacking the Collection: Networks of Material and Social Agency In the Museum. New York: Springer, 2011. (One World Archaeology).

CAHN, Walter. Masterpieces: Chapters on the History of an Idea. Princeton: Princeton University Press, 1979.

CANDLIN, Fiona. Museums, Modernity and the Class Politics of Touching Objects. In: CHATTERJEE, Helen (ed). Touch in Museums: Policy and Practice in Object Handling. Oxford: Berg, 2008, p. 9-20.

CONLIN, Jonathan. Le 'Musée de marchandises' The origins of the Musée Cognacq-Jay. Journal of the History of Collections, Oxford, v. 12, n. 2, p. 193-202, 2000.

High Art and Low Politics: A New Perspective on John Wilkes. The Huntington Library Quarterly, San Marino, v. 36, n. 4, p. 357-381, 2001. 
CONLIN, Jonathan. The Nation's Mantelpiece. A History of the National Gallery. London: Pallas Athene, 2006.

CRANE, Susan A. (ed.). Museums and Memory. Stanford: Stanford University Press, 2000.

CRARY, Jonathan. Suspensions of Perception: Attention, Spectacle and Modern Culture. Cambridge: MIT Press, 1999.

Géricault, the Panorama, and Sites of Reality in the Early Nineteenth Century. Grey Room, Cambridge, v. 09, p. 5-25, 2002.

CUNO, James B. (ed.). Whose Culture?: the Promise of Museums and the Debate over Antiquities. Princeton: Princeton University Press, 2009.

CUNO, James B.; FITZGERALD, Michael; LEAMAN, Michael R.; METRO, Judy; POINTON, Marcia; ROSLER, Martha; ROTH, Michael S.. Money, Power, and the History of Art. The Art Bulletin, New York, v.79, n. 1, p. 6-27, 1997.

DANTO, Arthur. Transfiguration of the Commonplace: A Philosophy of Art. Cambridge: Harvard University Press, 1981.

DARIAN-SMITH, Kate; PASCOE, Carla (ed.). Children, Childhood and Cultural Heritage. London; New York: Routledge, 2012.

DASTON, Lorraine. The Glass Flowers. In: DASTON, Lorraine (ed.). Things That Talk: Object Lessons from Art and Science. New York: Zone Books, 2004, p. 223-256.

DEAZLEY, Ronan; KRETSCHMER, Martin; BENTLY, Lionel (ed.). Privilege and Property: Essays on the History of Copyright. Cambridge: Open Book Publishers, 2010.

DEBARY Octave; TURGEON, Laurier (dir.). Objets et mémoires. Paris; Québec: Éditions de la Maison des Sciences de l'Homme; Presses de l'Université Laval, 2007.

DENEKE, Bernward; KAHSNITZ, Rainer (ed.). Das kunst- und kulturgeschichtliche Museum im 19. Jahrhundert. Vorträge des Symposions im Germanischen Nationalmuseum, Nürnberg. Munich: Prestel, 1977.

DIAS, Nélia. La mesure des sens: les anthropologues et le corps humain au XIXe siècle. Paris: Aubier, 2004 .

DUDLEY, Sandra, et al. (ed.). Narrating Objects, Collecting Stories. London; New York: Routledge, 2012.

DUNCAN, Carol; WALLACH, Allan. The Universal Survey Museum. Art History, London, v. 3, n.4, p. 448-69, dec. 1980 .

DUNCAN, Sally Anne. From Period Rooms to Public Trust: The Authority Debate and Art Museum Leadership in America. Curator: The Museum Journal, New York, v. 45, n. 2, p. 93-108, 2002.

EDWARDS, Elizabeth; GOSDEN, Chris; PHILLIPS, Ruth B. (dir.). Sensible Objects. Colonialism, Museums and Material Culture. Oxford; New York: Berg, 2006.

EFFROS, Bonnie. Selling Archaeology and Anthropology: Early Medieval Artefacts at the Expositions Universelles and the Wiener Weltausstellung, 1867-1900. Early Medieval Europe, Oxford, v.16, n.1, p. 23-48, 2008. 
ELKINS, James. Pictures and Tears: a History of People who Have Cried in Front of Paintings. London; New York: Routledge, 2004.

EMERY, Elizabeth Nicole. Consuming the Past: The Medieval Revival in Fin-de-siècle France. Aldershot; Burlington: Ashgate, 2003.

Photojournalism and the Origins of the French Writer House Museum (1881-1914):

Privacy, Publicity, and Personality. Aldershot; Burlington: Ashgate Publishing, 2012.

FALSER, Michael. Krishna and the Plaster Cast. Translating the Cambodian Temple of Angkor Wat in the French Colonial Period. Transcultural Studies, Heidelberg, v. 2, p. 6-50, 2011.

FINDLEN, Paula. The Museum: its Classical Etymology and Renaissance Genealogy. Journal of the History of Collections, Berkeley; Los Angeles: v.1, n.1, p. 59-78, 1989.

FREEDBERG, David. The Power of Images: Studies in the History and Theory of Response. Chicago: Chicago University Press, 1991.

FYFE, Gordon. Reproductions, Cultural Capital and Museums: Aspects of the Culture of Copies. Museum and Society, Leicester, v. 2, n.1, p. 47-67, 2004.

GAEHTGENS, Thomas W. Die Berliner Museumsinsel im Deutschen Kaiserreich: zur Kulturpolitik der Museen in der wilhelminischen Epoche. Munich: Deutscher Kunstverlag, 1992.

GELL, Alfred. Art and Agency - an Anthropological Theory. Oxford: Clarendon Press, 1998.

HALL, Stuart. Museums of Modern Art and the End of History. In: HALL, Stuart; MAHARAJ, Sarat. Modernity and Difference, London: Institute of International Visual Arts, 2001, p.8-23. (Annotations, n.6).

HAMON Philippe. L'image exposée: Musées. In: Imageries. Littérature et image au XIXe siècle. Paris: José Corti, 2001.

HASKELL, Francis. The Ephemeral Museum: Old Master Paintings and the Rise of the Art Exhibition. New Haven: Yale University Press, 2000

HENARE, Amiria. Museums, Antbropology and Imperial Exchange. New York: Cambridge University Press, 2005.

HENNION, Antoine; LATOUR, Bruno. How to Make Mistakes on So Many Things at Once and Become Famous for It. In: GUMBRECHT, Hans Ulrich; MARRINAN, Michael (ed.). Mapping Benjamin: The Work of Art in the Digital Age. Stanford: Stanford University Press, 2003, p. 91-97.

HIGONNET, Anne. A Museum of One's Own: Private Collecting, Public Gift. New York: Periscope, 2009.

HILL, Kate. Culture and Class in English Public Museums, 1850-1914. Burlington: Ashgate, 2005.

HOSKINS, Janet. Agency, Biography and Objects. In: TILLEY, Chris et al. Handbook of Material Culture. London: Thousand Oaks, 2006, p. 74-84. 
HUDSON, Kenneth. A Social History of Museums: What the Visitors Thought. London; Basingstoke: Macmillan, 1975.

JENKINS, Ian. Archaeologists and Aesthetes in the Sculpture Galleries of the British Museum 1800-1939. London: The Trustees of the British Museum; British Museum Press, 1992.

JENSEN, Lote; LEERSSEN, Joepe; MATHIJSEN, Marita (ed.). Free Access to the Past. Romanticism, Cultural Heritage and the Nation. Leiden; Boston: Brill, 2010.

JEVONS, Stanley. The Use and Abuse of Museums. In: Methods of Social Reform and Other Papers. London: Macmillan, 1883.

KAPLAN, Flora E. S.. Museums and the Making of Ourselves: the Role of Objects in National Identity. Leicester: Leicester University Press, 1994.

KESNER, Ladislav. The Role of Cognitive Competence in the Art Museum Experience. Museum Management and Curatorship, Guildford, v. 21, n.1, p. 4-19, 2006.

KNELL, Simon J. The Culture of English Geology, 1815-1851. Aldershot; Burlington: Ashgate, 2000.

KOPYTOFF, Igor. The Cultural Biography of Things: Commoditization as a Process. In: APPADURAI, Arjun (ed.). The Social Life of Things: Commodities in Cultural Perspective. Cambridge: Cambridge University Press, 1986, p. 64-91.

LASC, Anca I. Interior Decorating in the Age of Historicism: Popular Advice Manuals and the Pattern Books of Édouard Bajot. Journal of Design History, Oxford, v.26, n.1, p. 1-24, 2013.

LATOUR, Bruno. We Have Never Been Modern. New York: Harvester Wheatsheaf, 1993.

. From Realpolitik to Dingpolitik: Or How to Make Things Public. In: LATOUR, Bruno; WEIBEL, Peter (ed.). Making Things Public: Atmospheres of Democracy. Cambridge: MIT Press, 2005.

LAYTON, Robert. Art and Agency: a Reassessment. Journal of the Royal Anthropological Institute, London, v. 9, n.3, p. 447-464, 2003.

LEHMANN-BRAUNS, Susanne; SICHAU, Christian, TRISCHLER, Helmuth.The Exhibition as Product and Generator of Scholarship. Berlin: Max Planck Institute, 2010. (Preprint 399).

LENAIN, Thierry. Art Forgery: The History of a Modern Obsession. London: Reaktion, 2011.

LEWIS, Geoffrey. For Instruction and Recreation: a Centenary History of the Museums Association. London: Quiller Press, 1989.

LOIR, Christophe. L'émergence des Beaux-Arts en Belgique. Institutions, artistes, public et patrimoine (1773-1835). Brussels: Editions de l'Université de Bruxelles, 2004.

LONG, Véronique. Mécènes des deux mondes. Les collectionneurs donateurs du Louvre et de l'Art Institute de Chicago 1879-1940. Rennes: Presses universitaires de Rennes, 2007.

LORENTE, Jesús Pedro. The Development of Museum Studies in Universities: from Technical Training to Critical Museology. Museum Management and Curatorship, Guilford, v. 27, n. 3, p.237-252, 2012. 
MACDONALD, Sharon; FYFE, Gordon (ed.). Theorizing Museums: Representing Identity and Diversity in a Changing World. Cambridge: Blackwell, 1996.

MACLEOD, Dianne Sachko. Art and the Victorian Middle Class: Money and the Making of Cultural Identity. Cambridge: Cambridge University Press, 1996.

MAROSI, Erno; KLANICZAY Gábor (ed.). The Nineteenth-Century Process of "Musealization" in Hungary and Europe. Budapest: Collegium Budapest. 2006.

MCCAULEY, Anne. "Merely Mechanical": On the Origins of Photographic Copyright in France and Great Britain. Art History, Oxford, v.31, n.1, p.57-78, 2008.

MACGREGOR, Neil. A Pentecost in Trafalgar Square. In: CUNO, James B. (ed.). Whose Muse? Art Museums and the Public Trust. Princeton; Oxford: Princeton University Press; Cambridge: Harvard University Art Museum, 2004.

MINIHAN, Janet. The Nationalization of Culture: The Development of State Subsidies to the Arts in Great Britain. London: Hamilton, 1977.

MOSER, Stephanie. The Devil is in the Detail: Museum Displays and the Creation of Knowledge. Museum Anthropology, Flagstaff, v. 33, n.1, p.22-32, 2010.

MURRAY, David. Museums, their History and their Use. Glasgow: James MacLehose and Sons, 1904.

NELSON, Robert S. The Slide Lecture, or the Work of Art "History" in the Age of Mechanical Reproduction. Critical Inquiry, Chicago, v.26, n.3, p.414-434, 2000.

NOORDEGRAAF, Julia. Strategies of Display: Museum Presentation in Nineteenth and Twentieth Century Visual Culture. Rotterdam: Museum Boijmans Van Beuningen, 2004.

ORLANDO, Francesco. Gli oggetti desueti nelle immagini della letteratura: rovine, reliquie, rarità, robaccia, luoghi inabitati e tesori nascosti. Torino: Einaudi, 1993.

PATEY, Caroline; SCURIATTI, Laura (ed.). The Exhibit in the Text: The Museological Practices of Literature. Oxford; New York: Peter Lang, 2009.

PAUL, Carole (ed.). The First Modern Museums of Art: The Birth of an Institution in Eighteenth- and Early Nineteenth-Century Europe. Los Angeles: Getty Publications, 2012.

PERGAM, Elizabeth A. The Manchester Art Treasures Exhibition of 1857: Entrepreneurs, Connoisseurs and the Public. Surrey; Burlington: Ashgate. 2011.

PETY, Dominique. Poétique de la collection au XIXe siècle. Du document de l'historien au bibelot de l'esthète. Paris: Presses universitaires de Paris Ouest, 2010.

POINTON, Marcia R. Strategies for Showing: Woman, Possession, and Representation in the English Visual Culture 1665-1800. Oxford: Oxford University Press, 1997.

. Brilliant Effects: a Cultural History of Gem Stones and Jewellery. New Heaven: Paul Mellon Centre in British Art / Yale University Press, 2009.

POINTON, Marcia R. (ed.). Art Apart: Art Institutions and Ideology Across England and North America. Manchester: Manchester University Press, 1994. 
POMMIER, Edouard. (ed.). Les musées en l'Europe à la vielle de l'ouverture du Louvre. Paris: Louvre; Klincksiek, 1995.

POULOT, Dominique. Musée, nation, patrimoine, 1789-1815. Paris: Gallimard, 1997.

POULOT, Dominique (ed.). Goûts privés et enjeux publics dans la patrimonialisation XVIIIe-XXIe siècle. Paris: Publications de la Sorbonne, 2012a.

Letters to Miranda and Canova on the Abduction of Antiquities from Romeand Athens. Los Angeles: Getty Research Institute, 2012b.

RIONNET, Florence. L'Atelier de moulage du musée du Louvre 1794-1928. Paris: Réunion des musées nationaux, 1996.

SALLES, Georges. The Museums of France. Museum, Paris, v.1-2, p. 7-10, 1948.

SHAW, Wendy M. K. Possessors and Possessed: Museums, Archaeology, and the Visualization of History in the Late Ottoman Empire. Berkeley: University of California Press, 2003.

SHAYA, Gregory. The Flâneur, the Badaud and the Making of a Mass Public in France circa 1860-1910. The American Historical Review, New York, v. 109, n. 1, p. 41-77, feb. 2004.

SHEEHAN, James J.. Museums in the German Art World from the End of the Old Regime to the Rise of Modernism. Oxford: Oxford University Press, 2000.

SHERMAN, Daniel J.; ROGOFF, Irit (ed.). Museum Culture: Histories, Discourses, Spectacles. Minneapolis: University of Minnesota Press, 1994.

SMITH, Anthony D. Chosen Peoples. Oxford: Oxford University Press, 2003.

The Antiquity of Nations. Cambridge: Polity Press, 2004.

STANISZEWSKI, Mary Anne. "The Eye Is a Nobler Organ": Ruskin and American Art Education. Journal of Aesthetic Education, Urbana, v. 18, n.2, p.51-64, 1984.

The Power of Display: A History of Exhibition Installations at the Museum of Museum of Modern Art. Cambridge: MIT Press, 1998.

STARN, Randolph. A Historian's Brief Guide to New Museum Studies. The American Historical Review, New York, v. 110, n. 1, p. 68-98, 2005.

STOCKING, George W. (ed.). Objects and Others: Essays on Museums and Material Culture. Madison: Wisconsin University Press, 1985.

TAMEN, Miguel. Friends of Interpretable Objects. Cambridge: Harvard University Press, 2009.

TAYLOR, Brandon (ed.). Art for the Nation: Exhibitions and the London Public, 1747-2001. Manchester: Manchester University Press, 1999.

THOMAS, Nicholas. Entangled Objects. Exchange, Material Culture and Colonialism in the Pacific. Cambridge; London: Harvard University Press, 1991.

VAN KALCK, Michèle. Le musée et la vie culturelle à Bruxelles. In: Les Musées royaux des Beaux-Arts de Belgique. Deux siècles d'histoire. Bruxelles: Racine; Dexia, 2003. 
VERHOOGT, Robert Maarten. Art in Reproduction: Nineteenth-century Prints After Lawrence Alma-Tadema, Jozef Israëls and Ary Scheffer. Amsterdam: Amsterdam University Press, 2007.

VERMEULEN, Ingrid R. Picturing Art History. The Rise of the Illustrated History of Art in the Eighteenth Century. Amsterdam: Amsterdam University Press, 2010.

VINCENT, Odile. Collectionner?: territoires, objets, destins. Paris: Créaphis, 2011.

WATSON, Watson, Janell. Literature and Material Culture from Balzac to Proust: the Collection and Consumption of Curiosities. Cambridge: Cambridge University Press, 1999.

WHITEHEAD, Christopher. Museums and the Construction of Disciplines. Art and Archeology in Nineteenth-Century Britain. London: Duckworth, 2009.

WRIGHT, Gwendolyn (ed.). The Formation of National Collections of Art and Archeology. Washington: The National Gallery of Art, 1996. 